\title{
KARAKTERISTIK MUTU SABUN KOPI DENGAN VARIASI WAKTU PENCAMPURAN DAN WAKTU FRAMMING
}

\section{QUALITY CHARACTERISTICS OF COFFEE SOAP WITH A VARIATION OF MIXING TIME AND FRAMMING TIME}

\author{
Latifah Rabani ${ }^{1)}$ \\ 1) PP3MD Kabupaten Kepahiang, Bengkulu \\ Email : latifah_rabani@gmail.com
}

\begin{abstract}
ABSTRAK
Bubuk kopi mengandung kafein antara 1-1,5\%. Kafein merupakan senyawa kimia alkoloid yang bermanfaat untuk kesehatan kulit seperti memperbaiki kulit yang rusak, dapat menetralkan kulit yang teriritasi dan memberi nutrisi pada kulit, serta menghilangkan bau badan. Sehingga bubuk kopi dapat dijadikan bahan baku pengulahan sabun. Sabun merupakan bahan logam alkali (basa) dengan rantai asam monocarboxylic yang panjang. Tujuan penelitian ini adalah untuk menganalisis kadar lemak, kadar $\mathrm{pH}$, kandungan air, serta keretakan pada sabun kopi.

Metode dalam penelitian ini meliputi proses pembuatan sabun kopi dengan variasi waktu framming (3,5 dan 7 hari) dan lama pencampuran (15 dan 25 Menit). Proses pembuatan sabun kopi meliputi pencampuran 1 (minyak zaitun, minyak kelapa, minyak sawit, bubuk kopi), pencampuran 2 (ditambahkan larutan $\mathrm{NaOH}$ ) dan pencampuran ke 3 (ditambahkan pewangi), selanjutnya dicetak. Setelah proses framming (3,5,7 hari), sabun kopi disimpan selama 4 minggu. Kemudian sabun kopi dianalisis kandungan air, kadar $\mathrm{pH}$, dan lemak.

Dari hasil analisa kadar air pada sabun kopi berkisar 20,70 hingga 35,52\%. Kandungan pH berkisar 10,29 hingga 11,40, kandungan lemak pada sabun kopi berkisar 0,41 hingga 0,57. Nilai keretakan pada sabun kopi adalah 1 hingga 2 (tidak ada keretakan dan sedikit keretakan). Sedangkan hasil uji organoleptik untuk warna berkisar 2,90 (agak menarik) hingga 4,30 (menarik). Hasil uji organoleptik tekstur sabun kopi berkisar 2,55 (lunak) hingga 4,20 (keras). Hasil uji organoleptik daya berbusa sabun kopi berkisar 2,85 (agak berbusa) hingga 4,10 (berbusa)
\end{abstract}

Kata Kunci : sabun kopi, framming, mutu, waktu pencampuran

\section{ABSTRACT}

Coffee powder contains caffeine between 1-1,5\%, Caffeine is an alkaloid chemical compound, which is beneficial for skin health as repair damaged skin, can neutralize irritated skin ,nourish the skin, and eliminate body odor, so it can be used as raw material processing soap. Soap is an alkali metal (alkaline) with a long chain Monocarboxylic acid. The purpose of this research was to analyze the axunge content, $\mathrm{pH}$ levels, water content, as well as cracks in the soap coffee.

Methods in this research include the process of making soap coffee, with a variety of framming time soap coffee ( 3,5 and 7 days) and the effect of mixing time ( 15 and 25 minutes ). The process of making soap coffee involves mixing 1 ( olive oil, coconut oil, palm 
oil, coffee powder), mixing 2 (added a solvent of $\mathrm{NaOH}$ ) and mixing 3 (added deodorizer), then printed.After the process of framming (3,5,7 days), the soap coffee is stored for 4 weeks. Then soap can be analyzed water content, $p H$ levels, and axunge.

From the analysis, water content in soap coffee between 20,70 to 35,52\%, pH content in soap coffee between 10,29 to 11,40, axunge content in soap coffee between 0,41 to 0,57. Value cracking of the soap coffee is 1 to 2 (no cracks and little cracks), while result of organoleptic analisys for colors between 2,90 (rather attractive) to 4,30 (attractive), result of organoleptic analisys for texture of soap coffee between 2.55(soft) to 4.20 (hard), result of organoleptic analisys for foaming power of soap coffee between 2,85 (rather foamy) to 4,10 (foamy).

Keywords : coffee soap, framming, quality, mixing time

\section{PENDAHULUAN}

Dalam menjaga kesehatan, kebersihan tubuh merupakan hal yang sangat penting. Sabun merupakan benda wajib yang kita pakai setiap hari, tanpa sabun mandi terasa tidak bersih karena sabun berfungsi untuk mengangkat kotoran yang menempel pada tubuh kita. Dewasa ini pemanfaatan sabun sebagai pembersih kulit makin menjadi trend dan beragam. Keragaman sabun yang dijual secara komersial terlihat pada jenis, warna, wangi dan manfaat yang ditawarkan. Keberadaan sabun yang hanya berfungsi sebagai alat pembersih dirasa kurang megingat pemasaran dan permintaan masyarakatakan nilai lebih dari sabun. Oleh karena itu tidak ada salahnya jika dikembangkan lagi sabun yang mempunyai nilai lebih, seperti pelembut kulit, antioksidan mencegah gatal-gatal,dan pemutih dengan penampilan (bentuk, aroma dan warna) yang menarik serta memberikan zat-zat gizi dan nutrisi yang sangat diperlukan bagi kulit serta membantu memelihara kulit dengan mempertahankankelembaban kulit, membantu pertumbuhan sel-sel baru jika terjadi kerusakan sel kulit pada sabun kesehatan busa harus lembut dan sifat basanya lebih rendah (Spitz,1996).

Saat ini banyak sekali jenis-jenis sabun kesehatan yang ditawarkan, diantanya sabun kopi, selain dikonsumsi ternyata kopi juga bermanfaat untuk kesehatan kulit. Kandungan kafein dalam kopi merupakan antioksidan yang mampu mencegah penuaan dini pada kulit. Kafein banyak memiliki manfaat dalam bidang obat-obatan dalam dunia medis. Kafein berfungsi untuk merangsang aktivitas susunan syaraf dan meningkatkan kerja jantung sehingga jika dikonsumsi dalam jumlah berlebihan akan bersifat racun dengan menghambat mekanisme susunan syaraf manusia (Hodgson dan Levi,1987).

Kopi seperti halnya tanaman lain mengandung ribuan komponen kimia 
dengan karakteristik yang berbeda-beda. Walaupun kopi merupakan tanaman yang paling banyak diteliti, tetapi masih banyak komponen dari kopi yang belum diketahui baik dalam bentuk biji, maupun bentuk minuman, Kopi juga mempunyai manfaat untuk kesehatan kulit seperti mengencangkan kulit, mengurangi selulit mencerahkan wajah, melembabkan kulit, menghalus kulit, menghilangkan flek hitam dan bekas jerawat, menurunkan resiko kanker kulit.

$$
\text { Jenis kopi yang sering }
$$
dibudidayakan kopi robusta, arabika dan liberika. Penggolongan kopi tersebut umumnya didasarkan pada spesiesnya kecuali robusta. Kopi robusta bukan merupakan nama spesies karena kopi ini merupakan keturunan dari beberapa spesies kopi terutama Coffea canephora (Najianti dan Daniarti, 1997). Pada proses pembuatan sabun tahapan pencampuran dan framming merupakan tahapan yang penting, dimana pada saat proses pencampuran minyak dan lemak akan membentuk sabun murni, dan pada tahapan framming terjadi proses cairan sabun murni menjadi bentuk padatan. Framming memerlukan waktu 3-7 hari agar sabun dapat dipotong-potong, untuk mendapatkan sabun dengan padatan yang sempurna simpanlah potongan sabun 4 minggu dengan suhu kamar dengan kadar air 8-18 \% maka sabun siap untuk digunakan. Dengan penyimpanan tersebut tidak ada lagi reaksi kimia yang terjadi pada saat sabun digunakan, sehingga sabun aman untuk dipakai. Oleh karena itu pentingnya mengkaji pengaruh lama waktu pencampuran dan waktu framming terhadap kualitas sabun kopi.

\section{METODE PENELITIAN}

\section{Bahan}

Bahan baku dalam penelitian ini adalah bubuk kopi cap jempol yang diperoleh dari Pasar Kepahiang, minyak zaitun merk Selva, minyak kelapa merk barco, minyak kelapa sawit merk Fortune, $\mathrm{NaOH}$, air mineral merk Aquades, pengharum fragance.
Alat
Alat yang digunakan adalah timbangan digital, sendok plastik, wadah untuk mencampur bahan, cetakan, blender, erlenmeyer $250 \mathrm{ml}$, neraca analitik, buret $50 \mathrm{ml}$, pipet tetes.

\section{Prosedur Penelitian}
Rancangan yang digunakan dalam penelitian ini yaitu rancangan Acak Kelompok (RAK) dengan dua faktor yaitu :
Waktu pencampuran
P1 = Pencampuran selama 15 menit
P2 = Pencampuran selama 25 menit
Lama Framming 
F1 = Waktu Framming 3 hari

F2 = Waktu Framming 5 hari

F3 = Waktu Framming 7 hari

\section{Pembuatan Sabun Kopi}

Penelitian dilakukan pada pembuatan sabun Kopi dengan dengan variasi waktu pencampuran dan waktu framming. Berikut adalah tahapan pembuatan sabun kopi :

1. Minyak zaitun 235 gram, minyak kelapa 150 gram, minyak sawit 100 gram dan kopi 50 gram dicampur ke dalam blender selama 5 menit

2. $\mathrm{NaOH} 74$ gram dilarutkan ke dalam air sejuk/dingin 210 gram dalam wadah dari stainlees steel.

3. Larutan $\mathrm{NaOH}$ tersebut akan panas dan berwarna keputihan, selanjutnya dinginkan dalam suhu ruang

4. Larutan $\mathrm{NaOH}$ yang telah dingin dimasukan kedalam campuran belender hingga mengental dengan variasi waktu pencampuran 15 dan 25 menit

5. Selanjutnya dimasukkan pengharum fragrance $10 \mathrm{cc}$ kedalam blender dan putar blender selama 5 menit

6. Adonan yang sudah terbentuk dimasukan ke dalam cetakan dilakukan framming dengan variasi 3 hari, 5 hari, dan 7 hari.

7. Sabun dipotong-potong sesuai dengan bentuk yang diinginkan
8. Disimpan selama 4 minggu kemudian dianalisis.

\section{Analisis penelitian}

Analisis penelitian menggunakan analisa pengaruh lama waktu pencampuran (15 menit dan 25 menit) dan waktu framming (3 hari, 5 hari, dan 7 hari) pada pembuatan sabun kopi dengan 6 perlakuan, parameter yang diamati adalah kadar air, kadar asam lemak, PH, tingkat keretakan (cracking) dan organoleptik.

\section{HASIL DAN PEMBAHASAN}

\section{Kadar Air Sabun Kopi}

Banyaknya air yang terkandung pada sabun akan mempengaruhi kelarutan sabun. Semakin banyak air yang terkandung dalam sabun maka pada saat digunakan sabun akan semakin mudah menyusut (Langingi et al., 2012). Prinsip dari pengujian kadar air sabun adalah pengukuran kekurangan berat setelah pengeringan pada suhu $105^{\circ} \mathrm{C}$. Tingkat kekerasan sabun sangat dipengaruhi oleh kadar air sabun. Semakin tinggi kadar air maka sabun akan semakin lunak (SNI, 1994).

Hasil rerata analisa kadar air pada sabun kopi dengan perlakuan lama pencampuran 15 menit dan 25 menit,serta variasi waktu framming 3 hari, 5 hari dan 7 hari dapat dilihat pada tabel 1 . 
Tabel 1. Rerata Analisis Kadar Air Sabun Kopi

\begin{tabular}{|c|c|c|}
\hline \multirow{2}{*}{ Waktu Framming } & \multicolumn{2}{|c|}{ Kadar Air (\%) } \\
\cline { 2 - 3 } & Pencampuran 15 Menit & Pencampuran 25 Menit \\
\hline 3 Hari & $27.59^{\mathrm{c}}$ & $35.52^{\mathrm{a}}$ \\
\hline 5 Hari & $29.29^{\mathrm{b}}$ & $20.64^{\mathrm{d}}$ \\
\hline 7 Hari & $20.70^{\mathrm{d}}$ & $29.62^{\mathrm{b}}$ \\
\hline
\end{tabular}

Keterangan : Angka yang diikuti oleh huruf yang berbeda menunjukan adanya perbedaan yang nyata pada taraf $5 \%$

Tabel 1 menjelaskan rerata hasil analisis kadar air pada sabun kopi berbeda nyata dengan perlakuan lama pencampuran 15 menit, sedangkan pada perlakuan lama pencampuran 25 menit menunjukan berbeda nyata. Rerata kadar air pada sabun kopi dengan perlakuan lama waktu framming 3 hari dan lama pencampuran 15 menit sebesar $27.59 \%$, sedangkan lama pencampuran 25 menit sebesar $35.52 \%$, perlakuan waktu framing 5 hari dan lama pencampuran 15 menit sebesar $29.27 \%$ sedangkan lama pencampuran 25 menit sebesar $20.64 \%$, perlakuan waktu framming 7 hari dan lama pencampuran 15 menit sebesar $27.70 \%$ sedangkan lama pencampuran 25 menit sebesar $29.62 \%$.

Penurunan kadar air pada sabun kopi berbeda nyata, artinya semakin lama waktu pencampuran maka Kadar Air semakin tinggi dan semakin Lama waktu framming maka semakin menurun kadar air pada sabun kopi, sabun kopi yang terlalu tinggi kadar airnya akan mudah berbau tengik dan lembek, tentu saja berpengaruh pada kwalitas sabun.

Pada penelitian kali ini perlakuan pencampuran dengan waktu 15 menit dan waktu framing 5 hari yang menunjukan kadar air yang terendah dengan hasil kadar air $20.64 \%$. Kadar air pada sabun sangat dipengaruhi oleh variable-variabel waktu, suhu, kecepatan pencampuran, pada kondisi pencampuaran dan framming air dalam sabun menguap sehingga kandungan air dapat diminimalkan, hasil analisis menunjukan bahwa lama penyabunan tidak berpengaruh nyata terhadap kadar air sabun kopi, namun perlakuan framing berbeda nyata, semakin lama waktu framming kadar air semakin menurun. Hal ini disebabkan olehh sabun yang mengandung dekstrin (senyawa hidrolik) lebih banyak mengikat air karena air dalam sabun tidak dapat keluar dengan baik. Dekstrin merupakan senyawa 
hidrolik yang akan mengikat air serta akan membentuk system koloidal dan air sulit dilepaskan kembali.

\section{Kadar pH Sabun Kopi}

Sabun pada umumnya mempunyai pH sekitar 10 (Mitsui, 1997). $\mathrm{pH}$ merupakan indikator potensi iritasi pada sabun (Gehring, 1991). Apabila kulit terkena cairan sabun, $\mathrm{pH}$ kulit akan naik beberapa menit setelah pemakaian meskipun kulit telah dibilas dengan air. Pengasaman kembali terjadi setelah lima sampai sepuluh menit, dan setelah tiga puluh menit $\mathrm{pH}$ kulit menjadi normal kembali (Wasita, 1997) yaitu sekitar 4,56,5 (Tranggono, 2007). Alkalinasi dapat menimbulkan kerusakan kulit apabil kontak berlangsung lama, misalnya pada tukang cuci, pembilasan tidak sempurna, atau $\mathrm{pH}$ sabun yang sangat tinggi (Wasita, 1997). Hasil rerata analisa Kandungan $\mathrm{pH}$ pada sabun kopi dengan perlakuan lama pencampuran 15 menit dan 25 menit,serta variasi waktu framming 3 hari, 5 hari dan 7 hari dapat dilihat pada tabel 2.

Tabel 2 menjelaskan rerata hasil analisis $\mathrm{pH}$ pada sabun kopi berbeda nyata dengan perlakuan lama pencampuran 15 menit, sedangkan pada perlakuan lama pencampuran 25 menit menunjukan berbeda nyata. Rerata kadar pH pada sabun kopi dengan perlakuan lama waktu framming 3 hari dan lama pencampuran 15 menit sebesar 11.30 sedangkan lama pencampuran 25 menit sebesar 10.29, perlakuan waktu framing 5 hari dan lama pencampuran 15 menit sebesar $\quad 11.40$ sedangkan lama pencampuran 25 menit sebesar 10.31, perlakuan waktu framming 7 hari dan lama pencampuran 15 menit sebesar 11.32 sedangkan lama pencampuran 25 menit $\quad$ sebesar $\quad 10.36$.

Tabel 2. Rerata Analisis Kandungan pH pada Sabun Kopi

\begin{tabular}{|c|c|c|}
\hline \multirow{2}{*}{ Waktu Framming } & \multicolumn{2}{|c|}{ Kandungan pH } \\
\cline { 2 - 3 } & Pencampuran 15 Menit & Pencampuran 25 Menit \\
\hline 3 Hari & $11.30^{\mathrm{d}}$ & $10.29^{\mathrm{d}}$ \\
\hline 5 Hari & $11.40^{\mathrm{a}}$ & $10.31^{\mathrm{d}}$ \\
\hline 7 Hari & $11.32^{\mathrm{c}}$ & $10.36^{\mathrm{b}}$ \\
\hline
\end{tabular}

Ket : Angka yang diikuti oleh huruf yang berbeda menunjukan adanya perbedaan yang nyata pada taraf $5 \%$. 
Penurunan $\mathrm{pH}$ pada sabun kopi berbeda nyata, artinya semakin lama waktu pencampuran maka $\mathrm{pH}$ sabun kopi akan menurun dan semakin lama waktu framming maka semakin meningkat $\mathrm{pH}$ pada sabun kopi. Hal ini disebabkan oleh semakin besar kadar alkali bebas maka menentukan nilai $\mathrm{pH}$, yaitu nilai menunjukan tingkat basa atau asam suatu bahan.

Derajat keasaman atau $\mathrm{pH}$ digunakan untuk menyatakan tingkat keasaman atau kebasaan suatu larutan. $\mathrm{pH}$ sabun yang baik adalah 9.0-10.8 (Gusviputri, 2013). Sabun kopi yang terlalu tinggi kadar $\mathrm{pH}$ disebabkan oleh terjadinya hidrolis sabun. Sabun yang terlalu tinggi kadar $\mathrm{pH}$ dapat meningkatkan absorbsi kulit, sehingga kulit menjadi iritasi seperti luka, gatal, atau terkelupas dan dapat menyebabkan kulit menjadi kering.

Pada penelitian ini perlakuan pencampuran dengan waktu 25 menit dan waktu framing 3 hari yang menunjukan kadar $\mathrm{pH}$ yang paling rendah dengan hasil kadar pH 10,29. Sabun dengan pH 9-10 mampu membersihkan kotoran dari lapisan atas kulit dan melarutkannya dalam air pembilas, pada pencampuran yang lebih lama akan meningkatkan kapasitas saponifikasi $\mathrm{pH}$ sabun akan cendrung menurun, semua minyak bereaksi secara sempurna, karena residu $\mathrm{NaOH}$ semakin kecil, karena alkali telah bareaksi lebih sempurna dengan asam lemak pada minyak.

\section{Kadar Lemak Sabun Kopi}

Jumlah lemak yang digunakan dalam proses pembuatan sabun harus dibatasi karena kelayakan ekonomi, spesifikasi produk (sabun tidak mudah teroksidasi, mudah berbusa dan mudah larut). Lemak merupakan senyawa lipid yang memiliki struktur berupa ester dari gliserol. Lemak yang telah dipisahkan dari jaringan asalnya mengandung sejumlah komponen yaitu lipid kompleks, sterol yang terikat dengan asam lemak atau bebas, asam lemak bebas, lilin, pigmen yang larut dalam lemak, hidrokarbon.

Rantai hidrokarbon dalam suatu asam lemak dapat bersifat jenuh atau dapat pula mengandung ikatan-ikatan rangkap.asam lemak yang tersebar paling merata dalam alam, yaitu asam oleat, mengandung satu ikatan rangkap. (Fassenden, 1992).

Hasil rerata analisa kandungan lemak pada sabun kopi dengan perlakuan lama pencampuran 15 menit dan 25 menit, serta variasi waktu framming 3 hari, 5 hari dan 7 hari dapat dilihat pada tabel 3 . 
Tabel 3. Rerata Analisis Kandungan Lemak pada Sabun Kopi

\begin{tabular}{|c|c|c|}
\hline \multirow{2}{*}{ Waktu Framming } & \multicolumn{2}{|c|}{ Kandungan Lemak (\%) } \\
\cline { 2 - 3 } 3 Hari & Pencampuran 15 Menit & Pencampuran 25 Menit \\
\hline 5 Hari & $0.48^{\mathrm{d}}$ & $0.52^{\mathrm{b}}$ \\
\hline 7 Hari & $0.57^{\mathrm{a}}$ & 0.49 \\
\hline
\end{tabular}

Ket : Angka yang diikuti oleh huruf yang berbeda menunjukan adanya perbedaan yang nyata pada taraf $5 \%$.

Tabel 3 menjelaskan rerata hasil analisis kadar lemak pada Sabun Kopi berbeda nyata dengan perlakuan lama pencampuran 15 menit, sedangkan pada perlakuan lama pencampuran 25 menit menunjukan berbeda nyata. Rerata kandungan lemak pada sabun kopi dengan perlakuan lama waktu framming 3 hari dan lama pencampuran 15 menit sebesar $\quad 0.48 \%$ sedangkan lama pencampuran 25 menit sebesar $0.52 \%$, perlakuan waktu framing 5 hari dan lama pencampuran 15 menit sebesar $0.57 \%$ sedangkan lama pencampuran 25 menit sebesar $0.49 \%$, perlakuan waktu framming 7 hari dan lama pencampuran 15 menit sebesar $0.51 \%$ sedangkan lama pencampuran 25 menit sebesar $0.41 \%$.

Penurunan kadar lemak pada sabun kopi berbeda nyata, artinya semakin lama waktu pencampuran semakin tinggi kadar lemak pada sabun kopi dan waktusemakin lama waktu framming maka semakin tinggi kadar lemak pada sabun kopi. lemak yang terdapat dalam sabun tetapi tidak sebagai senyawa natrium ataupun senyawa trigisela (lemak netral) lemak berhubungan dengan bau sabun apabila asam lemak melebihi standart $0.1 \%$ akan menyebabkan sabun menjadi tengik (Hika, 2009) dan menghambat proses pembersihan pada permukaan kulit.

Pada penelitian ini perlakuan pencampuran dengan waktu 25 menit dan waktu framing 7 hari yang menunjukan kadar lemak yang rendah dengan hasil kadar lemak 0,41\%.

\section{Tingkat Keretakan Sabun Kopi}

Keretakan dapat disebabkan sejumlah faktor seperti bentuk batangan (sabun), tingkat distorsi (penyimpangan) kekosongan selama pencetakan (stamping), komposisi jumlah bahan pewangi (fragrance) dan bahan-bahan aditif. Ada dua jenis cracking, dinamakan kering dan basah (dry cracking dan wet 
cracking). Cracking kering dikarenakan celah yang disebabkan oleh udara yang masuk ke dalam sabun selama tekanan akhir. Cracking basah terjadi pada batangan sabun selama penggunaan untuk mencuci dan biasanya menimbulkan garis-garis keretakan pada batangan sabun (Iftikhar, 1981).

Palm oil (PO) adalah minyak semi padat yang berasal dari mesocarpium buah sawit, Elaesis guineensis. Palm Stearine (PS) adalah fraksi dari PO dan salah satu sumber yang paling murah lemak C16 - C18 yang digunakan dalam pembuatan sabun. Bagaimanapun, PO mempunyai beberapa pembatasan ukuran ketika digabungkan ke dalam formulasi sabun mandi. Sabun keras yang dihasilkan cenderung menjadi retak pada kondisi kering ataupun basah.
Fenomena keretakan sabun (cracking) merupakan satu dari sekian masalah yang cukup serius bagi pembuat sabun. Karena keretakan sabun dapat menimbulkan keluhan konsumen baik sebelum pemakaian maupun setelah pemakaian sabun. Uji keretakan sabun kopi pada penelitian ini adalah cracking basah (wet cracking) yaitu sabun dipakai hingga beratnya berkurang $1 / 4$ dari berat awal, lalu rendam dalam air selama 1 jam, setelah itu diangkat dandikeringkan selama 24 jam, pastikan permukaan sabun kering lalu lihat keretakannya.

Hasil rerata analisa keretakan pada sabun kopi dengan perlakuan lama pencampuran 15 menit dan 25 menit, serta variasi waktu framming 3 hari, 5 hari dan 7 hari dapat dilihat pada tabel 4 .

Tabel 4. Rerata Analisis Keretakan pada Sabun Kopi

\begin{tabular}{|c|c|c|}
\hline \multirow{2}{*}{ Waktu Framming } & \multicolumn{2}{|c|}{ Keretakan } \\
\cline { 2 - 3 } & Pencampuran 15 Menit & Pencampuran 25 Menit \\
\hline 3 Hari & $2^{\mathrm{a}}$ & $1^{\text {cde }}$ \\
\hline 5 Hari & $2^{\mathrm{a}}$ & $1^{\mathrm{de}}$ \\
\hline 7 Hari & $1^{\text {cde }}$ & $1^{\mathrm{d}}$ \\
\hline
\end{tabular}

Ket : $1=$ tidak ada keretakan, $2=$ sedikit retak (kurang dari 3), $3=$ retak, $4=$ Kertakan parah (lebih dari $2 \mathrm{~mm}$ ). Angka yang diikuti oleh huruf yang berbeda menunjukan adanya perbedaan yang nyata pada taraf $5 \%$. 
Tabel 4 menjelaskan rerata hasil analisis keretakan pada sabun kopi tidak berbeda nyata dengan perlakuan lama pencampuran 15 menit, sedangkan pada perlakuan lama pencampuran 25 menit menunjukan berbeda nyata. Rerata keretakan pada sabun kopi dengan perlakuan lama waktu framming 3 hari dan lama pencampuran 15 menit sebesar 2 (sedikit retak) sedangkan lama pencampuran 25 menit sebesar 1 (tidak ada keretakan) perlakuan waktu framing 5 hari dan lama pencampuran 15 menit sebesar 2 (sedikit retak) sedangkan lama pencampuran 25 menit sebesar 1 (tidak ada keretakan) perlakuan waktu framming 7 hari dan lama pencampuran 15 menit sebesar 1 (tidak ada keretakan) sedangkan lama pencampuran 25 menit sebesar 1 (tidak ada keretakan). Perlakuan pencampuran dengan waktu dan waktu framing menunjukan keretakan yang rendah.

\section{Organoleptik Warna Sabun Kopi}

Warna merupakan salah satu unsur yang dapat dijadikan indikator mutu sabun. Penilaian organoleptik warna sabun dengan cara menilai tingkat warna dari sabun yang dihasilkan tanpa penambahan bahan pewarna. Hasil rerata organoleptik warna pada sabun kopi dengan perlakuan lama pencampuran 15 menit dan 25 menit, serta variasi waktu framming 3 hari, 5 hari dan 7 hari dapat dilihat pada tabel 5 .

Tabel 5 menjelaskan rerata hasil organoleptik warna pada sabun kopi perlakuan lama pencampuran 15 menit dan 25 menit menunjukan berbeda nyata. Rerata warna sabun kopi dengan perlakuan lama waktu framming 3 hari dan lama pencampuran 15 menit sebesar 3.30 (agak menarik) sedangkan lama pencampuran 25 menit sebesar 4.15 (menarik), perlakuan waktu framing 5 hari dan lama pencampuran 15 menit sebesar 2.90 (agak menarik) sedangkan lama pencampuran 25 menit sebesar 4.00 (menarik), perlakuan waktu framming 7 hari dan lama pencampuran 15 menit sebesar 3.70 (menarik) sedangkan lama pencampuran 25 menit sebesar 4.30 (menarik). Warna pada sabun kopi diambil dari warna asli kopi. Semakin lama waktu pencampuran dan waktu framming maka warna sabun akan semakin menarik karena pewarna yang digunakan adalah pewarna alami, maka dalam penggunaan sabun kopi akan aman. Pada penelitian kali ini perlakuan pencampuran dengan waktu 25 menit dan waktu framing 7 hari yang menunjukan warna sabun kopi menarik dengan hasil warna 4.30. Penambahan waktu pencampuran menyebabkan warna yang semakin gelap. 
Tabel 5. Rerata Organoleptik Warna Sabun Kopi

\begin{tabular}{|c|c|c|}
\hline \multirow{2}{*}{ Waktu Framming } & \multicolumn{2}{|c|}{ Warna } \\
\cline { 2 - 3 } & Pencampuran 15 Menit & Pencampuran 25 Menit \\
\hline 3 Hari & $3.30^{\mathrm{c}}$ & $4.15^{\mathrm{a}}$ \\
\hline 5 Hari & $2.90^{\mathrm{d}}$ & $4.00^{\mathrm{ab}}$ \\
\hline 7 Hari & $3.70^{\mathrm{b}}$ & $4.30^{\mathrm{a}}$ \\
\hline
\end{tabular}

Ket Skala : $1=$ tidak menarik ; $2=$ kurang menarik ; $3=$ agak menarik ; $4=$ menarik ; $5=$ sangat menarik Angka yang diikuti oleh huruf yang berbeda menunjukan adanya perbedaan yang nyata pada taraf $5 \%$.

\section{Organoleptik Tekstur Sabun Kopi}

Penilaian organoleptik tekstur dilakukan dengan cara melihat dan merasakan tekstur atau tampilan sabun transparan yang dihasilkan kemudian menilainya berdasarkan skala penerimaan. Hasil rerata uji organoleptik tekstur pada sabun kopi dengan perlakuan lama pencampuran 15 menit dan 25 menit,serta variasi waktu framming 3 hari, 5 hari dan 7 hari dapat dilihat pada tabel 6 .

Tabel 6 menjelaskan rerata hasil uji organoleptik tekstur sabun kopi perlakuan lama pencampuran 15 menit dan 25 menit menunjukan berbeda nyata. Rerata organoleptik tekstur sabun kopi dengan perlakuan lama waktu framming 3 hari dan lama pencampuran 15 menit sebesar 2.75 (agak lunak) sedangkan lama pencampuran 25 menit sebesar 3,85 (keras), perlakuan waktu framing 5 hari dan lama pencampuran 15 menit sebesar 2.95 (agak lunak) sedangkan lama pencampuran 25 menit sebesar 4.00 (keras), perlakuan waktu framming 7 hari dan lama pencampuran 15 menit sebesar 2.55 (lunak) sedangkan lama pencampuran 25 menit sebesar 4.20 (keras). Tekstur pada sabun kopi sangat dipengaruhi oleh bahan dasar yang digunakan namun pada penelitian kali ini perlakuan juga dapat berpengaruh pada tekstur sabun kopi, terkstur sabun kopi berbeda nyata, artinya semakin lama waktu pencampuran dan waktu framming maka sabun akan semakin keras. Pada penelitian kali ini perlakuan pencampuran dengan waktu 25 menit dan waktu framing 7 hari yang menunjukan tektur sabun kopi menjadi keras dengan hasil tekstur 4.20. 
Tabel 6 Rerata Organoleptik Tekstur Sabun Kopi

\begin{tabular}{|c|c|c|}
\hline \multirow{2}{*}{ Waktu Framming } & \multicolumn{2}{|c|}{ Tekstur } \\
\cline { 2 - 3 } 3 Hari & Pencampuran 15 Menit & Pencampuran 25 Menit \\
\hline 5 Hari & $2.75^{\mathrm{b}}$ & $3.85^{\mathrm{a}}$ \\
\hline 7 Hari & $2.95^{\mathrm{b}}$ & $4.00^{\mathrm{a}}$ \\
\hline
\end{tabular}

Ket Skala : $1=$ sangat lunak ; $2=$ lunak ; $3=$ agak lunak ; $4=$ keras $; 5=$ sangat keras Angka yang diikuti oleh huruf yang berbeda menunjukan adanya perbedaan yang nyata pada taraf $5 \%$

Tekstur sabun yang terbentuk akibat lamanya proses penyabunan berbeda, semakin sedikit proses penyabunan adonan sabun yang dihasilkan lebih encer dan antara minyak dan alkali belum tercampur merata, sehingga minyak belum semuanya tersabunkan. Tekstur berhubungan dengan kadar air yang terkandung dalam sabun kopi. Peningkatan kadar air akan mengakibatkan tekstur semakin lunak.

\section{Organoleptik Daya Berbusa Sabun} Kopi

Penilaian organoleptik terhadap banyak busa dilakukan dengan cara membasuh tangan dengan sabun transparan yang dihasilkan kemudian menilai banyaknya busa yang dihasilkan berdasarkan skala penerimaan. Hasil rerata uji organoleptik daya berbusa pada sabun kopi dengan perlakuan lama pencampuran 15 menit dan 25 menit,serta variasi waktu framming 3 hari, 5 hari dan 7 hari dapat dilihat pada tabel 7 .

Tabel 7 menjelaskan rerata hasil uji organoleptik daya berbusa pada sabun kopi dengan perlakuan lama pencampuran 15 menit dan 25 menit menunjukan berbeda nyata. Rerata organoleptik daya berbusa sabun kopi dengan perlakuan lama waktu framming 3 hari dan lama pencampuran 15 menit sebesar 2.85 (agak berbusa) sedangkan lama pencampuran 25 menit sebesar 4.05 (berbusa), perlakuan waktu framing 5 hari dan lama pencampuran 15 menit sebesar 3.45 (agak berbusa) sedangkan lama pencampuran 25 menit sebesar 3.90 (berbusa), perlakuan waktu framming 7 hari dan lama pencampuran 15 menit sebesar 3.75 (berbusa) sedangkan lama pencampuran 25 menit sebesar 4.10 (berbusa). 
Tabel 7 Rerata Organoleptik Daya Berbusa Sabun Kopi

\begin{tabular}{|c|c|c|}
\hline \multirow{2}{*}{ Waktu Framming } & \multicolumn{2}{|c|}{ Daya Berbusa } \\
\cline { 2 - 3 } & Pencampuran 15 Menit & Pencampuran 25 Menit \\
\hline 3 Hari & $2.85^{\mathrm{d}}$ & $4.05^{\mathrm{ab}}$ \\
\hline 5 Hari & $3.45^{\mathrm{c}}$ & $3.90^{\mathrm{ab}}$ \\
\hline 7 Hari & $3.75^{\mathrm{b}}$ & $4.10^{\mathrm{a}}$ \\
\hline
\end{tabular}

Ket Skala : $1=$ tidak berbusa $; 2=$ kurang berbusa $; 3=$ agak berbusa $; 4=$ berbusa $; 5=$ sangat berbusa Angka yang diikuti oleh huruf yang berbeda menunjukan adanya perbedaan yang nyata pada taraf $5 \%$

Karakteristik busa dipengaruhi oleh adanya bahan aktif yang digunakan serta kadar lemak yang terkandung dalam sabun kopi, pada penelitian kali ini busa pada sabun kopi berbeda nyata, artinya semakin lama waktu pencampuran dan waktu framming maka sabun akan semakin berbusa. Pada penelitian kali ini perlakuan pencampuran dengan waktu 25 menit dan waktu framing 7 hari yang menunjukan daya berbusa yang tinggi dengan hasil daya berbusa 4.10 .

Pada proses pencampuran kedua penentuan daya busa pada sabun, karena pada pencampuran kedua ada penambahan larutan $\mathrm{NaOH}$, larutan yang sudah dingin sempurna serta didukung dengan lamanya pencampuran akan meningkatkan daya busa sabun, karena daya busa terbentuk pada saat proses saponifikasi.

\section{KESIMPULAN}

Berdasarkan hasil analisis kandungan air sabun kopi berkisar 20,64\% hingga 35,52\%, kadar $\mathrm{pH}$ berkisar $10,29 \%$ hingga 11,40\%, kandungan lemak berkisar 0,41\% hingga $0,57 \%$. Berdasarkan hasil rerata analisis keretakan pada sabun kopi berkisar antara 1 hingga 2 (tidak ada keretakan dan sedikit retak). Berdasarkan hasil rerata analisis uji organoleptik warna, tekstur dan daya berbusa sabun kopi menunjukan berbeda nyata. Nilai rerata analisis terhadap warna sabun kopi berkisar 2,90 (agak menarik) hingga 4,30 (menarik), analisis tekstur berkisar 2,55 (lunak) hingga 4,20 (keras), analisis daya berbusa berkisar 2,85 (agak berbusa) hingga 4,10 (berbusa)

\section{DAFTAR PUSTAKA}

Anggraini, Atik 2015 : Optimasi Waktu Perbandingan Ampas 
Kopi dengan Pelarut

Heksana Pada Ekstrasi

Minyak Ampas Kopi Arabika

(Coffe arabica.L) Untuk

Pembuatan Biodiesel"

Skripsi Fakultas Sains dan

Teknologi Universitas Islam

Negeri Sunan Kalijaga

Yogyakarta

Clarke, Macrae. 1985 : “ Pembuatan dan Karakteristerisasi sabun padat berbahan dasar VCO dan susu kambing dengan penambahan minyak kayu manis sebagai farfum "fakultas Matematika dan Ilmu Pengetahuan Alam Universitas Gajah Mada

Fessenden, 1992 : "Pemanfaatan Limbah Industri Kulit sebagai Bahan Dasar Pembuatan Sabun" Jurnal teknik Kimia Fakultas Teknologi Industri UPN Jawa Timur

Hodgson dan levi, 1987 : “ Pembuatan Sabun

Transparan Padat dari minyak Jarak yang beraroma Terapi Bunga Mawar" Institut Teknologi Sepuluh November

Iftikhar Ahmad,1981 :" Studi Perbandingan Campuran Minyak Palm Oil/Palm Stearine/Palm Karnel Oil (\%b\%b) Terhadap Keretakan Sabun Mandi Padat" Fakultas Matematika dan Ilmu Pengetahuan Alam Universitas Sumatra Utara

Langingi, Raymon 2012 : “ Pembuatan Sabun Mandi Padat dari VCO yang Mengandung Karotenoid Wortel'Jurnal Mipa Unsrat Manado 1 (1) 20-23

Luis Spitz, 1996 : "Formulasi Kesediaan sabun Padat sari Beras (Oryza Sativa) sebagai
Anti Bakteri Terhadap

Staphyloccus Epidermidis"

Najiati, Danarti. 2004" Budidaya

Tanaman Kopi dan penanganan Pasca Panen" Penebar Swadaya. Jakarta

Perwitasari, dyah Suci 2011 "Pemanfaatan Limbah Industri Kulit Sebagai Bahan Dasar Pembuatan Sabun "Jurnal Teknik Kimia vol.5, No 2

Radji, Maksum 2007 “Uji Efektifitas Antimikroba Beberapa Merk Dagang Pembersih Tangan Antiseptik" Laboratorium Mikrobiologi dan Bioteknologi Departemen Farmasi FMIPA-UI,Depok, 16424

Rahardjo, Pudji. 2012. Panduan Budidaya dan Pengolahan Kopi Arabika dan Robusta. Penebar Swadaya. Jakarta

Sinaga, Rikardo 2014 : "Studi Pembuatan Sabun Dari Campuran Minyak Sawit Dengan Lemak Babi” Fakultas Pertanian Universitas Katolik Santo Thomas Sumatra Utara.

Siswoputranto, 1992 : "Panduan

Budidaya dan Pengolahan Kopi Arabika dan Robusta" Penebar Swadaya. Jakarta

Sari Tuti Indah, 2010 : "Pembuatan VCOdengan Metode Enzimatis dan Konversinya Menjadi Sabun Pada Transparan" Jurnal Teknik Kimia No. 3,Vol. 17 Jurusan Teknik kimiaFakultas Teknik Universitas Sriwijaya Palembang

Sudarmadji.S. 1989 : “Analisis Bahan Makanan dan Pertanian "Yogyakarta

Sudarmadji. S. 1997 : “ Prosedur Analisis Untuk Bahan 
Makanan dan Pertanian" Yogyakarta.

Taufik, Fauzan 2011: "Studi Perbandingan Campuran Minyak Palm Oil/Palm Stearine/Palm Karnel Oil (\%b\%b) Terhadap Keretakan Sabun Mandi Padat" Fakultas Matematika dan Ilmu Pengetahuan Alam Universitas Sumatra Utara

Wasita, Atmadja, 1997 : “ Potensi Teknologi Diversifikasi Limbah Kopi Menjadi Produk bermutu dan Bernilai Tambah" pusat Penelitian Kopi dan Kakao Indonesia

Wijaya Susinggih, 2010 : "Penggandaan Skala Produksi Sabun Cair dari Daur Ulang Minyak Goreng Bekas" Jurnal Teknologi Industri Pertanian Fakultas Teknologi Pertanian
Universitas Brawijaya

Malang

Wahyuningrum Indha 2005 : “ Pemanfaatan Minyak Goreng Bekas Untuk Pembuatan Sabun: Kajian Lama penyabunan dan Konsentrasi Dekstrin" Jurnal Teknologi Pertanian, Vol. 6 No. 3 Jurusan Teknologi Pertanian Fakultas Teknologi Pertanian Universitas Brawijaya malang.

Wiryo Widagdo,Sumali,2000 "Kimia dan Farmatologi Bahan Alam" Universitas Indonesia,Jakarta

Zulkifli, Mochamad 2014 : "Sabun dari Distilat Asam Lemak Minyak Sawit” Jurnal Pangan dan Agroindustri Vol.2 No 4 Universitas Brawijaya Malang 